\title{
Masha and Bear(s): A Russian Palimpsest
}

\author{
Olga Lyanda-Geller \\ Purdue University \\ West Lafayette, IN, USA
}

\begin{abstract}
When stories are scraped clean and re-written, how much of the original shines through later tales? This paper offers a palimpsest analysis (palimpsestos, "scratched/scraped again") of the story Masha and the Bear based on a Russian folktale, Tolstoy's tale The Three Bears, and the transformed folk world in the contemporary cartoon series Masha and the Bear. A palimpsest analysis of a text reveals different layers of readers', listeners', and viewers' expectations, allowing them to challenge the story. Bringing together different versions of a tale with seemingly very similar characters and plot lines, where each subsequent story is regarded as a palimpsest, adds new features to each story's interpretation. Considering the tale of Masha and the Bear, told differently in Russian folklore, literary tradition and modern media, demonstrates juxtaposition of textual layers that produces a variety of effects, from tragic to comic.
\end{abstract}

...а так как мне бумаги не хватило,

Я на твоем пишу черновике.

И вот чужое слово проступает...

Anna Akhmatova, Poem Without a Hero

[... and since my paper has run out,

I'm using your rough draft for writing.

And here a word not mine shows through...

Transl. Nancy K. Anderson]

Introduction

Due to the scarcity and expense of writing materials in the ancient world, people produced and reproduced different kinds of palimpsests, or texts written over older texts that had been previously erased, scraped away, washed out, or deleted in some other way, with the original purpose of saving parchment or papyrus. During the last two centuries, the term 'palimpsest' has been used mostly figuratively, referring to all sorts of texts, documents, places, etc., that contain traces of their predecessors.

The focus of this paper is the tale about a little girl, named Masha (Mashenka) in the Russian folk tradition, while nameless in some other versions, who is lost in the woods, where she meets a bear or bears, from whom she is supposed to escape. The story is told quite differently in the Russian folk version Masha and the Bear, Leo Tolstoy's fairy tale The Three Bears (1875), written as a part of his cycle of stories and fairy tales for young children, and the recent 
cartoon series Masha and the Bear (2009 - present). Bringing together different versions of a tale with seemingly similar characters and plot lines, where each subsequent story is regarded as a palimpsest with multiple references to the previous traditions, adds new features to each story's interpretation. Considering the tale of Masha and the Bear, told differently in Russian folklore, literary tradition and modern media, reveals various textual layers, which produces a variety of effects, from tragic to comic, on listeners, readers and viewers, allowing them to challenge their expectations and perspectives.

\section{A few remarks on palimpsest}

Before starting to read the story about Masha and the Bears as a palimpsest, let us briefly discuss the concept of palimpsest, and how it can be used methodologically in literary studies. It is difficult to find a discipline where the concept of palimpsest would not be known today. (1) As Sarah Dillon points out, recently it "has been employed in areas as diverse as architecture, geography, geology, palaeontology, glaciology, astrophysics, biochemistry, genetics, neuroscience, neurobiology, neurocomputing and information technology" [2007: $1]$.

Thomas De Quincey, who launched the use of the term in modern literature with his essay The Palimpsest [1845], defines it as "a membrane or roll cleansed of its manuscript by reiterated successions" [2003: 145]. The term 'palimpsest' (Greek $\pi \alpha \lambda i \mu \psi \eta \sigma \tau o \varsigma$, from $\pi \alpha \dot{\lambda} \imath \nu$, again, and $\psi \alpha \dot{\alpha} \omega$, I scrape) in its direct meaning refers to a text written on material from which previous writing has been deleted by scraping, erasing, or washing. (2) The process of removing the previous material and substituting it with a later writing could be repeated, resulting in something 'doubly palimpsest' [Thompson 2013: 64], or a second-order palimpsest. (3) Sometimes, the process can be repeated multiple times, thus generating hyper-palimpsests. The term 'hyper-palimpsest' (giperpalimpsest) was coined by the Russian linguist Andrey Zaliznyak, referring to the Novgorod Codex (Novgorodskii kodeks, also Novgorodskaia psaltyr'), a unique palimpsest found in 2000 in Novgorod. It is currently thought to be the oldest extant Russian book. Zaliznyak suggests calling the Novgorod Codex a hyper-palimpsest because it contains dozens of layers of texts [2002: 37].

Since Antiquity, the concept of palimpsest has been used in a number of ways in literary tradition and beyond. (4) In linguistics, Robert Galisson (1990s) suggests the special terms 'palimpsestes verbaux' and 'palimpsestes verboculturels' [verbal palimpsests and verbal-cultural palimpsests], referring to words and expressions that play on verbal and cultural stereotypes that conceal in themselves other words and expressions. An example of such a palimpsest is the advertisement Paris vaut bien un prix [Paris is well worth a prize], about an award for RATP, Autonomous Operator of Parisian Transports, as a palimpsest of Henri IV's famous 'Paris vaut bien une messe' [Paris is well worth a mass.] (5)

Literary criticism and methodology have looked at textual palimpsests from different angles (6), although Dillon's monograph is probably the only attempt at a systematic approach to the palimpsestuous (7) reading. Usually 'deciphering the 
codes,' or clarifying and interpreting allusions referring to other sources is not the main task of a literary analysis. In most cases, this is part of an integrative approach to a text as a whole. However, in the case of folktales, and of the folk tradition in general, considering them as palimpsests is particularly fruitful.

Folk wisdom as palimpsest

Due to the multilayered fabric of narration, many folktales are natural palimpsests. Like other examples of folk verbal art, they may go through different stages of transformation, and are rarely left intact. Sometimes, their message gets changed, or some contributing elements are altered or replaced by others, including their opposites. To demonstrate the productivity of reading folktales and related cultural and literary materials as palimpsests, let us offer an example of folk wisdom, where the original message is hidden by later changes.

Consider the proverb zhizn' prozhit' - ne pole pereiti [living a life is not like crossing a field/meadow]. It is usually referred to as self-explanatory: crossing a meadow is easy; however, life has never been easy, so living your life is not nearly as simple as crossing a meadow. Yet this variant seems to be a later version of the proverb with an opposite message: zhizn ' prozhit' - chto pole pereiti [living a life is like crossing a field/meadow]. (8)

The original message reflected the symbolic idea of the field as a border between the two worlds (own/foreign, life/death, etc.). Therefore, living a life was symbolically paralleled with crossing the border between the worlds, which was not to be understood as an easy adventure. Later the symbolic meaning faded, and was substituted by a simpler version; hence rewording of the proverb, with the change of the meaning to the opposite. Characteristically, in Vladimir Dal's dictionary of The Proverbs of the Russian [1862: 295], the proverb zhizn 'prozhit', ne pole pereiti is immediately followed by the proverb zhizn' prozhit', chto more pereplyt' [living a life is like swimming/sailing across a sea]. This proverb with its parallel structure makes a positive comparison. The first, transformed, proverb holds a palimpsestuous trace of the original message.

Generally, the later version of folk wisdom can be taken as self-sufficient, that is, it might be enough to understand just its own meaning, without any other reference. However, our understanding can be enriched if we can trace how this meaning originally appeared, and which cultural connotations it has acquired in the course of history. A palimpsestuous analysis uncovers these layers of meaning.

Russian folktale Masha and the Bear

The oldest of the three stories about the girl and the bear(s) is the Russian folktale Masha and the Bear (in the oral tradition, sometimes Mashen 'ka and the Bear.) There are a number of versions of the folktale. The variant the Russian children most often know is the story told by M. A. Bulatov [Anikin 1978: 1718]. In this version Masha keeps the Bear busy following her orders with the 
famous line 'ne sadis' na penek, ne esh' pirozhok!' ['Don't sit on the stump, don't eat the pie!']

A synopsis of the folktale includes the following steps: (1) Masha asks her grandparents to let her go to the forest to pick berries with her friends. They give her permission to go, but warn her to stay close to her friends; (2) She strays away from her friends and gets lost; (3) She finds a hut, which turns out to be a Bear's hut; (4) The Bear does not let her go home; (5) Masha bakes pies, and asks the Bear to take them to her grandparents; (6) The Bear agrees; Masha sneaks into the basket, and does not let the Bear eat pies or look into the basket; (7) He delivers the pies and runs away because of the dogs in the village; (8) Masha is safely reunited with her grandparents.

Analyzing this folktale and Tolstoy's version of the tale, we will follow the classical formal method suggested by Vladimir Propp in his seminal works Morphology of the Folktale [Morfologia skazki, 1928] and Historical Roots of the Wonder Tale [Istoricheskie korni volshebnoi skazki, 1946]. What matters for a palimpsest analysis here is that Masha and the Bear is an initiation story. (9)

The motive of initiation in folktales is palimpsestuous by nature: for the reader who is informed of the theory that the tales represent survivals of old initiation rites, it symbolically reconstructs the initiation rite as a very early form of social life. At the time of telling the story, the rite itself may or may not be still alive as a social phenomenon, but most likely has already undergone some transformation when narrated. In actual social practice, "[t]he novice whom initiation introduces to the mythological traditions of the tribe is introduced to the sacred history of the world and humanity" [Eliade 1965: xv]. In the folk world, the introduction happens symbolically, thus creating the oldest basic motive for folktales of this kind. The different motifs related to initiation unite into the 'initiation cycle' [Eliade 1965: xv]. This cycle is combined with the 'death cycle', or the circle of motifs describing folk ideas about death and the world of the dead, which provides the main constituents of some kinds of the folktale, in particular, of the wondertale.

Masha and the Bear is a very old story that reconstructs a symbolic model of the world, where characters and places must have their symbolic functions. Masha, the main character of the tale, behaves in a way that corresponds to her function of a novice passing through initiation. She has to submit to experiences she encounters and to gain new knowledge.

Initiation rites start with the character's separation from home or family. Masha's initiation begins when she leaves her grandparents. Masha knows that her initiation ritual has begun: she is the only girl to be lost in the forest. Masha's age is not specified, but the group of friends is referred to as 'devushki' [young girls], not 'devochki' [little girls]. She might be the youngest girl in the group, and her friends could have already completed their initiation. The story does not elaborate on this, and it is not important, since the story is about Masha's initiation. Since she belongs to the group, she is considered a 'devushka,' one of the young girls, or is close to their age, and therefore is qualified to begin her initiation. 
Although Masha is warned not to leave her friends, she violates this interdiction, gets lost, and starts to call for her friends when it is too late. The other girls are not looking for her: they also functionally 'know' that this is Masha's initiation: she must complete it on her own, without their help. Once she realizes that she is lost, Masha finds herself in a forest thicket, where she enters a hut. She does not try to escape from the Bear's hut, and this is not because the Bear warns her not to-after all, she has already neglected one warning. The girl knows she is not intended to find a way from the forest on her own. She stays with the Bear for a while, doing his housework and thinking about the ways to escape. Since she cannot do that on her own, Masha tricks the Bear into helping her, making him her involuntary ally.

The place where the rite of initiation occurs is also symbolic. As Mark Graham [2010: 422] notes, "[p]laces have always been palimpsests." If this is true of real places, it is even more so with symbolic places, and, more generally, with symbolic chronotopes, or space-time relations in the folk world [Uricchio 2012: 45-49]. The Bear's hut, the tiny house right in the middle of the woods, is the timeless, sacred site of the ceremony. The Bear, keeper of the hut and of the forest, promises Masha will stay with him forever. The Bear needs Masha to cook for him, which is a task for a woman, not a little girl. Masha has to say farewell to her childhood, to "the child's state of irresponsibility and happiness, of ignorance and asexuality," [Eliade 1965: 8] and to be reborn as an adult.

Masha's staying in the forest with the Bear represents a modified symbolic death as an element of initiation. The Bear himself serves as a master of initiation, which is very common for old tales: from the historico-cultural point of view, it suggests that "this type of initiation is the creation of the archaic hunter culture... The operators... incarnate the divinities in the animal form who in mythical times first performed initiatory murder" [Eliade 1965: 23]. The fact that in the end the Bear is chased away by the dogs adds to the hypothesis that the symbolic representation of the ritual in the folktale reconstructs an archaic practice from a hunter culture. As often happens, the master of initiation is an ambivalent figure, first representing some evil force that threatens the main hero, and then voluntarily or involuntarily transforming into a helper. For instance, the Baba Yaga often promises to do terrible things to the hero, but rarely actually does any harm.

There is no ritual 'killing' per se in the folktale, but there are other elements that unambiguously point to the novice's symbolic death, with her subsequent rebirth. Consider the way Masha tricks the Bear into helping get her home: she bakes pies, puts them into a basket [korob], hides inside it and makes the Bear carry the basket with her inside, the dish with the pies on her head. The basket is Masha's symbolic casket, from which she cannot get out on her own. During the trip, she must not be seen, and the Bear hears only her voice. Once she is safely delivered to her home, she stays in the basket until her grandparents open it to find her in good health. When Grandfather opens the lid, he "cannot believe his eyes" - apparently, Masha's family did not expect to see her alive; they truly consider her adventure in the forest as deadly.

The grandparents do not seem to be angry with Masha, although she did not follow their advice. On the contrary, they kiss her and praise her for being such a 
clever girl. In terms of the initiation ceremony, they congratulate her on having successfully passed the test. This is where the traditional folktale ends. In some other versions, one more sentence is added: "And Mashen'ka promised never to go to the forest alone" [Masha 2006: 2]. Naturally, this sentence is absent in the original, as the tale's primary message is not about keeping promises and following good advice. This last sentence was added for didactic purposes, and it is an example of palimpsestuous supplement.

It is essential for the story that Masha has grandparents, not parents. Since her family consists of old people, who cannot have children anymore, she must succeed in her endeavor; otherwise the life-death circle will not be complete. The absence of parents and the presence of grandparents are also quite common for archaic folktales.

Summarizing this part of Masha and the Bear's adventures, we can conclude that the Russian folktale belongs to the type of the archaic tales where the main conflict of the story and the characteristic functions of the heroes can be interpreted through the prism of the initiation rite. Such an interpretation invites us to treat the story as a palimpsest, due to its symbolic representation of a social practice by the means of folklore.

\section{The Three Bears by Tolstoy}

The tale The Three Bears is often thought to be a Russian folktale, while actually it is neither a folktale nor Russian by origin. In the version with which most Russian readers are familiar, it is not a folk story, for it has an author: Leo Tolstoy adopted an English story for his cycle of tales and short stories New ABC Book [Novaia azbuka, 1874] to instruct generations of young Russian readers.

Tolstoy considered educating children a very important task and spent quite a few years working and reworking on the $A B C$ Book and New ABC Book. (10) In a letter to his daughter Alexandra Tolstaya, he tells about his dream:

по этой «Азбуке» только будут учиться два поколения русских всех детей, от царских до мужицких, и первые впечатления поэтические получат из нее и что, написав эту азбуку, мне можно будет спокойно умереть

[using only this $\mathrm{ABC}$ book, two generations of all Russian children, from the tsars' to the peasants', will learn, and will receive their first poetic impressions from it, and that, having finished this $\mathrm{ABC}$ book, I will be able to die in peace.] [Tolstoy 1978: XII, 56]

A synopsis of The Three Bears includes some steps similar to the first story and some new ones: 1) A little girl is lost in the forest; 2) She finds a house and enters. The house belongs to three Bears who are out for a walk; 3 ) The girl finds three objects of different sizes (bowls, chairs, and beds), and tries them. Two of them are unacceptable for her; the third is "just right"; 4) She eats the Little Bear's (Mishutka's) food, breaks his chair, and falls asleep in his bed; 5) The Bears 
return, get mad, and find Masha; 6) Masha wakes up and escapes through the window. The Bears are not able to catch her.

Tolstoy retells the English story "The Three Bears," also known as The Story of the Three Bears, Goldilocks and the Three Bears, etc., recorded by Robert Southey, Joseph Jacobs, et al., which is arguably "one of the most popular fairy tales in the English language" [Elms 1977: 257]. It is not my point here to trace how much Tolstoy changed in the English original, while adopting the story for Russian readers. My main interest is to investigate what makes Tolstoy's fairy tale a palimpsest in the Russian tradition.

Goldilocks and the Three Bears can be interpreted in many ways. [Bettelheim 1976: 215-224; Elms 1977: 257-273; Tatar 2002: 245-252] Similarly to Goldilocks, Tolstoy's fairy tale can also be approached from different perspectives. Elms believes that the English tale "includes so few of the typical folktale elements identified by Propp that a standard morphological analysis of the tale would be virtually meaningless" [Elms 1977: 257]. However, such an analysis applied to Tolstoy's story gives quite interesting results. Leonid Chernov [2006], challenging the claim that The Three Bears does not contain many standard folktale elements, meticulously applies Propp's suggested sequence of thirty-one functions of dramatis personae characteristic for fairy tales, demonstrating the productivity of such an approach [1998: 23-50].

Before turning our attention to a morphological analysis, let us note several elements in Tolstoy's version that are not typical for a Russian folktale. First, the main human character does not have a name. Nameless boys and girls are quite common for Tolstoy's stories about little children from the The ABC Book. In the original English version, the main character is a fox or an old woman; later their place is taken by a little girl, Goldilocks. Tolstoy does not give a name for the girl, although, all the bears have names: father Bear is Mikhailo Ivanych, mother Bear is Nastas'ia Petrovna, and the bear cub's name is Mishutka. These are traditional names from the Russian animal epos, especially the father bear's names; it is quite common for Russian folktales not to provide the names of human characters, though other times they do. But it is certainly less common for children in Russian folktales not to have names. This is why, when the story is being retold in the oral tradition without reference to Tolstoy, the girl is often called Masha, or Mashen'ka, apparently, by analogy with Masha and the Bear and many other folktales. Although there is no name in Tolstoy's story, the folk mentality reads it as palimpsest, associates it with analogous stories, and names the girl "appropriately", making the story more 'personal.'

Second, in Tolstoy the girl does not have a family; at least, we do not know anything about her parents or grandparents. On the contrary, the Bears are a family. They live in a house. We know the girl lives somewhere, for the story tells us, "Odna devochka usha iz doma v les." [A girl left her house/home for the forest.] But this is all we learn about her home. Again, not only do the Bears have a house, on the contrary, but it is described in detail. Their house in the middle of the forest is not just a hut: it is furnished, with individual utensils and furniture for each family member (bowls, chairs, beds). When the girl enters the Bears' house, she uses, or rather, misuses things not intended for her: she eats Mishutka's 
porridge, breaks his chair, and sleeps in his bed. When found out, she jumps out of the window, but again, the story does not tell us about a family that she has to return to. The absence of a place/family for the heroine to return to is a significant issue. As we have seen, for the composition of initiation tales it is vital that the hero have a family and home. Initiation tales typically start with the hero's departing in some way (otluchka, 'absentation,' in Propp's terms), and end with the happy reunion of the hero, who has successfully overcome the obstacles and solved all puzzles, with his or her family or tribe. However, here there is no family for the girl to return to. She disappears into the forest.

So, is this an initiation story at all? Seemingly it is, but an odd one. Besides the absence of a traditional beginning, the story has a bizarre, suspenseful ending. When discovered by the angry Bears, she flees and disappears. Does this count as the mandatory 'happy ending?' On the one hand, the girl must be happy to escape from the Bears: "Devochka vyskochila v okno i ubezhala. I medvedi ne dognali ee." [The girl jumped out the window. And the Bears did not manage to catch her.] On the other hand, the story ends where it starts: the little girl is in the forest alone, perhaps lost again and doomed.

These considerations raise yet another question: is the story primarily about the girl? Strangely, the title suggests, it is not. It is not The Little Girl and Three Bears. However, titles can be misleading. As Umberto Eco notes:

[a] title, unfortunately, is in itself a key to interpretation. We cannot escape the notions prompted by The Red and the Black or War and Peace. The titles that show most respect for the reader are those that confine themselves to the name of the hero, such as David Copperfield or Robinson Crusoe; but even this reference to the eponymous character can represent an undue interference of the author... Perhaps the best course is to be honestly dishonest, as Dumas was: it is clear that The Three Musketeers is, in reality, the tale of the fourth. But such a luxury is rare, and it may be that the author can allow himself to enjoy it only by mistake [Eco 1994: 541-542].

It is not clear whether Tolstoy is being 'honestly dishonest' and the title The Three Bears gives us a key to interpretation, or whether the title is given by mistake.

Looking at Tolstoy's tale as a palimpsest, and using a morphological analysis, let us suggest a positive answer to both questions. Although seemingly an odd one, this is indeed an initiation story, and the initiated party is the girl who must be the main hero of the tale, even though the tale's title does not reflect that.

A key to addressing these questions can be found in the fact that The Three Bears is a literary tale [literaturnaia skazka], a tale that has an author [avtorskaia skazka]. There is no unanimity in literary criticism about the specifics of this kind of genre. There is not even a single view on whether literary tales should be considered a separate genre or sub-genre. (11) There seems to be at least one feature common to literary tales as a genre: they are original, culturally authentic stories. Tolstoy's story is indeed original in this sense. However, the folk basis of 
the tale is very strong. In fact, Tolstoy's referral to some of the most common folk motifs is very deliberate, as is, perhaps, his desire to make the story as close to the folk style one as possible, that this stylization should not be overlooked. The folk layer shows through in the new version of the story. The immanent property of its strikingly powerful 'folk origin' 'showing through' qualifies the new text as palimpsestous [Khomich 2006: 230-231]. And although The Three Bears is not a folk story, "Tolstoy's talent and the specific Soviet historical context have made the story a folktale, which is interesting on its own," [Chernov 2006]. In other words, Tolstoy's tale has acquired some genuinely folk, or in Propp's terms, 'mythical' features. (12)

Since authors usually compose their fairy tale according to a specific idea, not according to the schema required by a folktale, the authors' strategy may determine the reader's attitude. Sometimes the author's intention may not be evident to readers. As shown by Emilia Khomich's study of literary tales, based on the example of reading Evgeny Shvarts' Cinderella with high school and college students, the majority of readers do not understand the idea of remaking a folktale [Khomich 2006]. (13) However, Tolstoy's case is different. He does not remake a folktale, but creates an original work that he deliberately makes look like a folktale. Because his target audience is young children, his position can be defined as an educational one [prosveshchencheskaia pozitsiia] [Chernov 2006]. This position explains some of the unusual features of The Three Bears.

Let us now take a closer look at some of Propp's thirty-one functions, required by folktale narration. Some functions are fully developed in Tolstoy's tale, others are merged together, and a few are absent, reflecting the fact that it is not an authentic folktale, although it should be noted that even genuine folktales usually do not include all of Propp's functions.

F1. Absentation: "one of the members of the family absents himself from home." (14) This is where Tolstoy's story starts. However, as was mentioned, there is no family for the girl to be absent from. A formal reason for leaving is also lacking. It is not clear why the girl leaves home. F2. Interdiction: "an interdiction is addressed to the hero." There is no formal interdiction in the story. The girl does not have anyone to give her a good advice; to forewarn her about dangers in the forest. F3. Violation: "the interdiction is violated." This function is logically absent: if there no interdiction, it cannot be violated. F4. Reconnaissance: "the villain makes an attempt at reconnaissance." There is no villain [vreditel'] in the strict sense in the story. Indirectly, the forest itself could be represented at this stage as a villain, because it 'confuses' the girl, resulting in her getting lost in the woods [Chernov 2006]. F5. Delivery: "the villain receives information about his victim." The girl does not have any information to share, so the villain does not receive anything. F6. Trickery: "the villain attempts to deceive his victim." Again, indirectly, the forest deceives the girl by trapping her into the woods. F7. Complicity: "the victim submits to deception and thereby unwittingly helps his enemy." Incidentally, the appearance of a house in the forest can be taken as deception, because the girl could expect the house to belong to people, whereas it turns out to be the Bears' house. The forest, (which in the absence of other characters fulfills the role of the villain), lures the girl into the 'wrong' 
house. On the other hand, the house is not unambiguously 'wrong': before meeting the Bears, the girl finds food and rest there. Thus, in confusing her so that the girl finds the house, the forest simultaneously acts as a villain, and as a magic helper or donor.

Since Propp takes Functions 1-7 as preparatory for development of folktales, we can make provisional comments at this stage of the analysis. On the one hand, the structure of Tolstoy's story, at least in some elements, seemingly follows the folk structure that Propp represents as universal for wondertales. On the other hand, Tolstoy's narration definitely differs from the folk one. As Chernov notices, "we see a contradiction between a folktale form, a structure...by which The Three Bears is similar to classical folktales, and a specific author's content absolutely different from traditional" [2006].

F8. Villainy: "the villain causes harm or injury to a member of a family." So far there is no obvious harm done to the girl (as the only representative of her family). However, Propp explains that there is a vast assortment of forms of villainy, including a special sub-function 8a. 'lack': "one member of a family either lacks something or desires to have something." Here the girl is hungry and lacking food. At a glance, there is nothing wrong with the girl's desire and her subsequent eating of the food she finds in the house. However, the house and everything inside it are alien to the girl. In particular, the food is not intended for the girl. So, potentially there might be danger in tasting the food.

F9. Mediation: "misfortune or lack is made known." The girl realizes she is hungry and starts trying different food. Then she feels tired, tries different chairs and beds and finally falls asleep. From a child's perspective, everything seems just right, and logically the events follow one another. From the folktale perspective, the events demonstrate quite a different, ancient logic. The house, with all its 'help', is not all that innocent. From what we have seen in our analysis of Masha and the Bear, the house in the forest is the place for a ceremony of initiation. The girl, who is by now fully introduced as the hero of the story (she is now freely and boldly acting on her own, choosing what she pleases), has to die and be reborn symbolically in the forest. The food she finds in the house, which now acts as her symbolic 'tomb', can be seen as analogous to food for the deceased found in graves.

F10. Beginning counteraction: "the seeker agrees to, or decides upon counteraction." There is nobody, except the house itself, to guide the girl through her initiation, so she decides to act, or rather, counteract on her own. She does not just do what she needs to do (eating, resting, sleeping). She tries different sizes of all utensils and furniture (spoons, bowls, chairs, beds), until she finds the right one, which, of course, is the smallest item of each kind and belongs to the bear cub Mishutka. Since she is a little girl, logically it does not make sense for her even to try the other sizes that clearly will not suit her. However, following folktale logic, steps and elements are tripled, so the girl starts with the biggest item, then proceeds with the middle one, and finally uses the smallest. When she finds 'the right one', she even laughs, as it feels so good. The girl's laughter is particularly important. As Propp notices, "the early form of the magic of laughter is based on the idea that the dead do not laugh; only the living laugh. The dead 
coming to the realm of the dead cannot laugh; the living must not laugh" [1999: 254]. The girl breaks the rule; therefore, she is not 'dead' anymore.

F11. Departure: "the hero leaves home." Propp specifies that a special transference of the hero might be absent, and the entire action takes place in one location. Here the girl does not leave the house. She falls asleep, after having used the Bears' possessions. Most of the rest of the story happens while she is asleep. So, although she does not leave the house physically, she is not actively present there until Mishutka wakes her up. The girl's falling asleep in the house can be also treated as a symbolic death.

F12. The first function of the donor: "the hero is tested, interrogated, attacked, etc." This function usually indicates the initiation of the hero, because, depending on how well the hero answers the questions or faces the challenges, that is, how well the hero knows and follows the rules of the initiation rite, he or she either passes or fails the test. However, the girl is fast asleep, (after having freely chosen everything she wanted to try in the house and causing some trouble by moving the Bears' chairs into the wrong places and breaking Mishutka's chair, etc.), and is feeling quite safe there. None of the questions the hero is supposed to answer are addressed to the girl. She is sleeping and could not have heard them in any case. So, whom are the Bears addressing with their questions and threats? Apparently, the audience. The young readers associate themselves with the little girl, and (while she is asleep) they assume her role.

F13. The hero's reaction to the actions of the future donor and F14., Provision or receipt of a magical agent. There is neither a new character in the tale to perform the function of the donor, nor a magical agent in the traditional sense. The girl acts alone, she chooses what she wants in the house, thus combining the functions of both donor and recipient. The act of free choice is significant. In folktales, heroes cannot choose a magical gift. It is namely a 'gift,' for it is 'given,' not chosen. In general, Tolstoy gives the girl much more freedom than is allowed by folktales. Tolstoy wants the girl (and the reader, correspondently) to make choices deliberately; this is part of his educational project.

F15. Spatial transference: the girl is discovered and flees from the Bears. F16. Struggle: the hero and the villain join in direct combat. F17: Branding: the hero is branded (wounded/marked). Mishutka wants to bite the girl, but she escapes through the window. The motif of biting is significant there: biting is not exactly what one would expect from a bear, but it would leave a mark (that the initiated hero could demonstrate upon her return home). However, Mishutka does not succeed in biting the girl, and she escapes unharmed and unmarked. F18.: Victory: the Bears chase but do not manage to catch the girl.

Here the tale ends. If we were to find some of the other thirteen functions, we would have to come back to the same content we just analyzed, and look for them intertwined into the first eighteen. It is not unusual even for genuine folk wondertales to have functions inverted or reversed. Instead of going into a detailed analysis of the rest of the functions, (15) let us unite them into two sets. The first set describes events related to a problem and its resolution (F19, 21, 22, 25, 26, 28). These functions are represented by the girl's facing the forest and the Bears, and her escape. An analysis of these functions supports the main points of our 
argument made previously: Tolstoy offers his readers a text-palimpsest based off an initiation tale. The second set includes the functions that are not explicitly present in the story $(\mathrm{F} 20,23,24,27,29,30,31)$. Their absence is reflected in the unusual beginning and the end of the story, and the amount of freedom, unprecedented for folktales, that Tolstoy gives to the girl, thus allowing the young readers, together with the heroine, to challenge the traditional course of events and to make their own choices.

At this stage we can conclude that Tolstoy's story is a palimpsestuous initiation tale, where the strangeness of an overall successful initiation can be explained by The Three Bears being an original literary tale with a very strong folk base. Some traditional folktale elements are missing from the story; however, some other key elements are still present, including symbolic death and rebirth of the hero. Tolstoy, most likely, did not intend to offer a continuation or variation of the folktale Masha and the Bear. However, since this is an open-ended story, with no explicit moral at the end, young readers are supposed to draw conclusions themselves (such as, "Do not go alone to the forest. Do not get into trouble. But if you are in trouble - be brave, proactive, and creative.") Since Tolstoy intended this tale for reading, not listening, one can infer that he did not target the youngest children, but a slightly more mature audience. By the time his readers are able to read the story themselves, they should be familiar with the Russian folk tradition. Therefore, Tolstoy is counting on his readers to use their knowledge of the oral tradition and their imagination to fill in the gaps in the story, or, in other words, he is counting on his tale working as a palimpsest.

\section{Masha and the Bear(s), Soviet and Post-Soviet Animation}

Due to the immense popularity of the folktale about Masha and the Bear and of Tolstoy's story, it would be natural to expect various adaptations-palimpsests of both stories in Soviet and Russian animation. However, this was not the case until recently, when a cartoon series Masha and the Bear appeared and immediately became the subject of wide discussion. Before looking at the series, let us outline how Masha's story was treated in Soviet and Post-Soviet animation.

In the $20^{\text {th }}$ century there were two adaptations of the folktale: a puppet cartoon Mashen 'ka i Medved' [Mashenka and the Bear, 1960], and a musical puppet animation Mashen'ka [1992]. (16) There were also two adaptations of Tolstoy's tale, both keeping the original title The Three Bears: a cartoon about a girl named "Varvarushka" [1958], and a cartoon-opera [1984]. (17) In 1937, the studio Mosfilm made a black and white cartoon, also entitled The Three Bears (directors Maria Benderskaia and Mili Taut-Korso), loosely based on both folk and literary versions, where Masha does not take good care of her toys, and a plush teddy-bear Mishka runs away from her into the forest. Masha has a dream where she transforms into a doll and is caught by the Bears.

Although these cartoons focus on different aspects of the original stories, there is a striking detail common to all of them: they modify the end of the originals, apparently trying to adapt them to contemporary circumstances or providing an explicit moral message absent from the originals. In Aida 
Ziablikova's cartoon-opera [1984], although Mishutka is very upset (because, as in Tolstoy's tale, Masha eats Mishutka's porridge, breaks his chair, and sleeps in his bed), instead of trying to hurt Masha, the bear cub helps the girl, giving her a stool so that she could reach the high window through which she escapes. Then Mishutka keeps chasing her - but only to give the girl her forgotten bast shoes. In the end of Landau-Kachanov's tale [1960], Mashenka and the Bear become friends. The girl promises to teach the Bear how to read and write, and the Bear agrees to visit on holidays. In the 1992 version by Olifirenko, Masha behaves contrary to the Bear's expectations, appearing a helpless and awkward child, not the housewife he wanted, so he sends her back home. However, she helps him realize how lonely he is, and the cartoon ends with Mashenka's return and the duet that the girl and the Bear sing using a popular folk tune Kogda b imel zlatye gory [If I had golden mountains...]. Thus, all these adaptations change the original folk message, apparently finding it unclear, not sufficient, not illuminating enough, or simply not appealing to the audience. The initiation rite, if present, is significantly modified.

If there is a well-known and loved folktale or literary story, it is a common practice to create multiple adaptations of the story using different media: consider, e.g., adaptations of folktales and stories about Snegurochka or Kashchei Bessmertnyi. However, despite interest in Masha's story and the love of longer movie versions based on folktales, in the Soviet times there was no popular movie for children inspired by Masha's adventures in the forest. It is interesting to mention that there is a recent melodrama Masha and the Bear [2013, director Vladimir Fat'ianov, starring Olga Kras'ko and Nikita Zverev], rated 12+ in Russia (roughly corresponding to PG-13), clearly not suitable for younger children. The folktale title is used metaphorically in the movie, to give a clue to interpreting the story of a capricious and quarrelsome businesswoman, Marianna, who is stuck in the taiga with a huntsman, Yegor.

Many Soviet cartoons can be united by their common main character into a cycle about Masha (Mashenka) and her adventures. However, most of them, including those focusing specifically on a girl (or girls) lost in the forest and her (or their) meeting with the Bear (e.g., Chudesnyi kolokol'chik [The Wonderful Bell], 1949, based on the folktale Daughter and Stepdaughter, directors Valentina and Zinaida Brumberg), have a different folk or literary background than Masha and the Bear or The Three Bears. The absence of a bright and colorful version of the folk story in modern Russian cinema and animation may be what inspired the Animaccord studio to create a controversial but very moving cartoon with many palimpsestuous features that we shall discuss now.

\section{Masha and the Bear, Modern Cartoon Series (2009 - present)}

At first sight, what can be more typical for a Russian folktale than a story called Masha and the Bear? Indeed, this animation series is based on Russian folktales; the story starts where it should start, with a little girl getting lost in the woods where she finds a bear's hut. Other formal folktale elements are also present. However, everything turns out to be upside down in this world. Masha, 
the main character, is not afraid of the Bear and does not try to escape from him. Instead, she makes him her best friend, and each series starts with Masha visiting the Bear. Each visit usually turns out to be a catastrophe for him and other forest dwellers.

Masha is a restless little fidget with vivid imagination and a kind heart. She frequently visits her friend, the Bear, and demands much of his attention; her visits make his life unbearable. The Bear, whom Masha familiarly calls "Mishka", quite contrary to what one might expect from a bear in a folktale, is kind, caring, and endlessly patient with Masha. Playing on stereotypes depicting Russian bears riding a bicycle, the authors portray him as a former circus bear. Before meeting Masha, the Bear apparently enjoyed a calm and peaceful life in the forest. Now, after Masha has changed his world dramatically, he is always in trouble because of her. But the Bear loves Masha and forgives her for everything.

The Animaccord Studio makes a few bold claims explaining the project: "Masha and the Bear is the first Russian cartoon series that speaks the same language as children and adults all over the world ... It's a story of friendship. The characters' relationship reflects the relationship of a child who is learning the world, and an adult who tries to help the child... Despite the absence of direct didactics, each series wittily tells us about kindness, curiosity, and spontaneity." (18) However, not every audience agrees with these claims. The cartoon has provoked a wide range of reactions, varying from great admiration to aggressive criticism.

Judging by many negative comments and reviews the cartoon has received, many parents and teachers see Masha as a malicious character and find the story harmful and dangerous, because, according to them, it features an egoistic child who mistreats those around her. (19) However, many of these commentators seem to identify the cartoon with a folktale, or try to find an explicit moral there, as in a fable, forgetting that even in folktales the message is often quite far from being clear, to say nothing about attempting to apply such standards to a quasi-folktale. Masha and the Bear is told as a palimpsestuous humorous story that reevaluates and breaks numerous stereotypes. Young viewers are usually happy with nothing more than a bright and funny story. For a more mature audience, however, unpacking the hidden message requires adequate common sense, some knowledge of the folk background, and a good sense of humor. Although the authors claim that the cartoon is appropriate for children of age 3-9, (20) clearly very young readers will benefit from watching the cartoon together with their parents, because they will need some guidance to get the message of a particular episode, much as Masha needs the Bear to guide, teach, and even discipline her.

The cartoon Masha is given much more freedom than the girl in Tolstoy's tale, and incomparably more than Mashenka from the folktale. Masha is unconditionally free in the cartoon and has to learn how to tame her inner tyrant, for she is a not a true folk character who behaves according to her function. Watching the cartoon as a palimpsestuous story helps viewers interpret the story from different perspectives, seeing familiar features in Masha without identifying her with the authentic folk characters. She is very vivacious and curious (in folktales, some curiosity is also demonstrated, e.g., when the interdiction is 
violated, but this kind of curiosity is a built-in feature: the hero must violate the interdiction or there is no story). Masha's curiosity often leads her too far, and then the Bear is always there to help her. The cartoon, among other things, aims at developing a critical attitude in children. Masha is not presented as an exemplary character. She makes a lot of mistakes, but, with the adult's (the Bear's) help, she is learning to correct them.

As the animated series is quite long ( 52 episodes produced by the end of 2015), let us summarize a few of its palimpsestuous features. On the plot level, viewers typically face a crisis of expectations, for most of the characters' behavior is opposite to what is expected in the folk world. The cartoon picks up from both folktales (e.g., a little girl alone in the forest with a bear), and literary stories (e.g., Tolstoy's The Three Bears: the girl damages the Bears' mode of life, and escapes unharmed). In the episodes that are more based on the folk material, Masha is usually going through the rite of initiation, with all ceremonial elements present - and with the ceremony itself turning out wildly wrong. For example, in Episode 1, How They Met (Animaccord's translation, Russian version Pervaia vstrecha, The First Meeting), Masha, following Tolstoy's example of the girl who tries the Bear's bed and leaves it messed up, climbs into the Bear's bed and uses it as a trampoline. Not only is she not punished for having made such a mess, the Bear himself finds this activity fascinating, and the episode ends with him jumping on his bed. In Episode 5, Prances with Wolves (Russian version S vokami zhit'... [When in Rome...]), the Wolves kidnap Masha, hoping for a ransom from the Bear. Using Propp's classification of functions, this is the mandatory Function 8 where villains cause harm to the hero or a family member. However, the rest is far from the folk scenario: following O. Henry's The Ransom of Red Chief, rather than obedient folktale victims who patiently wait for someone to come and save them, Masha makes the Wolves' life so miserable that they end up paying the Bear and pleading with him to take Masha back. The palimpsestuous reference to The Ransom of Red Chief helps explain a lot in Masha's behavior, but it requires the viewers' acquaintance with O. Henry's short story. This is not hard to expect, given O. Henry's popularity in Russia, among an older audience, of course.

At the language level we find numerous word-palimpsests and palimpsestuous sentences that Masha coins at ease. Masha is the only character who actually expresses her thoughts verbally. All other characters (the Bear, the Wolves, the Bunny, etc.) understand language but do not speak. In Episode 4, Traces of Unknown Animals, Masha is particularly productive: after having mixed up different animals tracks and driving her teacher, the Bear, mad with her uneducability, Masha starts mixing up words. In the Song of Animal Tracks, she suggests meeting with nosobraz, dikorog, krokomot, begedil, popukan, peligai [rhinopine, porcunocerous, crocopotamus, hippodile, parrican, pelirot] and others. (21)

Masha is not always good with words, but this does not bother her. Whenever she does not understand a word or expression, she breaks the word into parts that make more sense to her, or changes parts of speech, simply creates new words, or uses other words by analogy with what she thinks she does know, 
following the logic of children's etymology (22) that help her and all children in the world clarify this strange 'grown-up' language:

Mishka! U menia tut fokus ne udalsia. Rasfokusirui menia!

[Mishka! My magic trick didn't come out well. Unfocus me!]

(misused word, formed according to a productive model, raz-/ras- [un-],

by analogy with, e.g., rasputai (Ep. 25, Hocus-pocus);

Ukh, ia takaia fotografichnaia!

[Oh, I am so photographic!]

(instead of fotogenichnaia, photogenic) (Ep. 34, 9x12 Picture);

Vo! Zalepukha kakaia!

[Here you are! Such glueness!]

(forming a new word, from zalepit', by analogy with zavarit' $\rightarrow$

zavarukha (Ep. 24, Bon appétit);

Tut u nas stolpotvoren'ie, eto ia stolpotvoriu!

[We've got turmoil here. I am the one who is turmoiling!]

(coining a new verb using the model varen'ie $\leftarrow$ variu) (Ep. 6, Lam Day)

Masha unpacks idioms and misquotes famous sayings as she pleases, producing more verbal cultural palimpsests, in Galisson's terms:

Ukh, ia takaia skoraia na pomoshch'!

[I am so emergenty!],

(contamination of skoryi na (ruku, pod''iom, etc.) and skoraia

pomoshch') (Ep. 5, Prances with Wolves);

A ia idu, guliaiu po Lune

[I am walking on the Moon],

(palimpsestuous A ia idu, shagaiu po Moskve, from a song from the

movie Walking the Streets of Moscow (Ep. 6, Lam Day);

Sladko zhit' ne zapretish'!

[Living sweet isn't against the law!]

(palimpsestuous playing with the idiom Krasivo zhit' ne zapretish'!

[Living well isn't against the law!] (Ep. 33, Sweet Life).

Masha's featured verbal cultural palimpsest is postel'nyi lezhim (playing with bed rest) where lezhim is a noun formed by abbreviated rezhim and lezhat' (Episode 3, One, two, three! Light the Christmas tree!). In this word play one might hear an echo from Sergey Dovlatov's famous saying, "Rezhim: naelis' $i$ lezhim" [1993: 271].

One last element of interest to discuss with regard to the palimpsestuous nature of the cartoon is the spin-off Masha's Tales [2012-2013, 26 episodes]. A spin-off is just one of many kinds of replications. Spin-offs are different from remakes, updates, adaptations, sequels, prequels, carryovers and other 'strategic 
reinventions.' (23) A spin-off “is a narrative work, derived from an existing work, with a particular focus on one aspect - a topic, character, or event - that was not central to the original." [Pfefferman 2013: 3] According to the authors, "Masha's Tales is a new project by Animaccord Studio that characterizes Masha from a different perspective. She tells well-known folktales from all over the world in her unique manner to her toys ("Doll" and "Mishka"): Masha mixes up plots and characters and finishes each story with an unexpected and amusing conclusion." (24) Masha does not speak much in the original cartoon, although the viewers are well aware of her vivid imagination; so the spin-off focuses on a new role for Masha starring her as a storyteller.

Masha's Tales can be classified as a double palimpsest, where the (quasi)folk character, which belongs to one level of palimpsest, refers to other folk and literary sources (the other level of palimpsest). Masha unleashes her imagination and tells folktales in her own way: she deviates from the original and freely fills in with her own explanations, just to make "more sense", as in Masha's version Red Riding Hood (Ep. 4). According to her, the moral of the fairytale is that you should visit your Grandma more often, so that you won't mix her up with a wolf. In the last episode of the spin-off series, The Humpbacked Horse (Ep. 26), Masha brings together at least five different easily identifiable literary sources (Pavel Ershov's The Little Humpbacked Horse, Lewis Carroll's Alice's Adventures in Wonderland, Korney Chukovsky's The Stolen Sun, Leonid Filatov's The Tale of Soldier Fedot, and Alexander Pushkin's Ruslan and Lyudmila), plus countless folk allusions. (25) One of the main characters in Masha's tale is Krokomot [Crocopotamus, or Crocopot], whom we have already met in Episode 4 of Masha and the Bear. Put in this new context, Crocomot is now recognizable as a palimpsestuous Barmaglot, Jabberwocky.

\section{Conclusion}

A palimpsest analysis of a text reveals different layers of readers', listeners', and viewers' expectations, allowing them to challenge the story. By bringing together different versions of the tale of Masha and the Bear in Russian folklore, literary tradition and modern media, we have shown that the juxtaposition of layers of the text produces a variety of effects, from tragic to comic.

Are palimpsestuous texts intentionally created as palimpsests? In other words, do authors deliberately create intertextual palimpsestuous parallels, and if this is not the case is it legitimate to read their texts as palimpsests? Did Tolstoy mean for his story to be regarded as inscribed into the folk tradition, or did the authors of the cartoon Masha and the Bear have in mind previous versions of the story? Perhaps they did not. Some ancient authors who erased previously written texts to create their own documents on papyrus had no clue about what they were writing upon and could only guess how much of the original texts would transpire through later writings. In much the same way modern authors may also be unaware of the extent to which their texts actually are palimpsestuous. However, one might want to adopt Umberto Eco's point of view on reading texts, especially palimpsestuous texts: 
Nothing is of greater consolation to the author of a novel than the discovery of readings he had not conceived but which are then prompted by his readers... the large majority of readings reveal effects of sense that one had not thought of. But what does not having thought of them mean? Did I know that I was playing with paragrams?.. (26) It is of no importance to reply now: the text is there and produces its own effects of sense [Eco 1994: 509].

The further the palimpsest story departs from the original story, though still being based on it, the more sophisticated the structure of the narration. Considering such stories as palimpsests, with numerous cross-references to other media, and in particular interpreting certain features (such as the initiation rite) as palimpsest, helps explain 'strange' issues. With palimpsest as a method of analysis, which helps to reveal new cultural, historic, sociological, folkloric, literary allusions, our understanding of stories becomes deeper.

\section{NOTES}

1 Sarah Dillon's The Palimpsest [2007] suggests a genealogy of the concept 'palimpsest' in literary studies.

2 The practice of re-using parchment and papyrus was known to the ancient Greeks, Romans, and Egyptians [Russell: 99]. Early uses of the term itself can be found in Cicero and Catullus. Cicero praises his friend Trebatius for writing his letters on palimpsest: Nam quod in palimpsesto, laudo equidem parsimoniam. Sed mirror quid in illa chartula fuerit, quod delere malueris... (Ad Fam., VII.18) [As to (your letters on) palimpsest, I truly praise you for your thrift. But I wonder what could have been on that piece of parchment that you preferred to delete...] (All translations are mine except where it is stated otherwise.) Catullus, in a letter to Varius, mocks at Suffenus, a prolific but artless poet, who seems to be so pleased with his work that he writes on 'royal papers', instead of humbly using palimpsest papers, as his contemporaries would do: ... nec sic ut fit in palimpsesto / relata: cartae regiae, novi libri... [... and not written on palimpsest but on the royal papers, new books...] [xxii]. Catullus uses words of Greek origin very rarely. [184] So, it is noteworthy that he actually uses the term 'palimpsest', and rather than just describing the concept as Martial does in his epigrams, e.g.: Esse puta ceras, licet haec membrane vocetur: / Delebis, quotiens scripta novare voles [Imagine them of wax, although these tablets are called parchment: you will be able to erase (them) as often as you wish to write anew] [Martial: 177].

3 The concept is treated figuratively as early as in Plutarch, when he reports that Plato compared Dionysius to a palimpsest: $\dot{\alpha} \lambda \lambda \lambda^{\prime} \varepsilon \tilde{v} \rho \varepsilon \Delta$ tovv́бıv

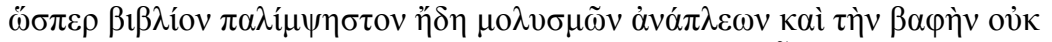

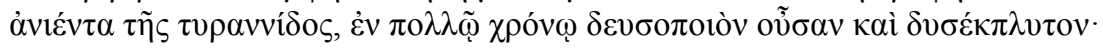
[but he (Plato) found Dionysius to be like a palimpsest book, already soiled with stains and unable of getting rid of his tyranny, for, with all this time passed, it stained through and is hard to clean out] [779c 1-4]. 
4 This concept used metaphorically is explored in Gérard Genette's famous Palimpsestes: La littérature au second degré [1982], where the author creates a typology of text relationship, which includes architextuality, intertextuality, paratextuality, metatextuality, and hypertextuality [1982: 1-6]. It is worth mentioning that these text relations reveal the specific property of the texts in question to refer to other texts; while the term 'palimpsest' refers to a particular text itself.

5 On the history of palimpsests see, in particular: Dillon [2007: 11-21]. For more specific uses in different periods, see also Josephine McDonagh [1987], Darby Lewes [2008], Raeleen Chai-Elsholz [2011] and Kim HainesEitzen [2011].

6 Among many interesting figurative uses of the term, one may mention:

7 A 'prison palimpsest', a term introduced by Cesare Lombroso [1888] to indicate erased inscriptions in prisons which allegedly could help understand prisoners' psychology (as mentioned by his daughter, Gina Lombroso-Ferrero, her father Cesare Lombroso in his book Prison Palimpsests [1888] "made a collection of all the inscriptions, drawings, and allegories scratched or written by criminals while in prison, on walls, utensils, and books... of lamentations, despair, and repentance, scarcely a trace, but innumerable imprecations, plans of revenge against enemies without, project of future burglaries and murders, and advice for the sound instruction of criminals" [Lombroso-Ferrero 1911: 155].

8 An 'alcoholic palimpsest', a term introduced by E. Morton Jellinek in a series of work [1942-1960], to refer to a case of blackout, or acute amnesia, caused by excessive alcohol ingestion.

9 See, e.g., Robert Galisson [1994, 1995], and Svetlana Pouchkova [2010: 161-163].

10 Besides the aforementioned works by Dillon and McDonaugh, see also Dorothy Colmer [1970], David Darby [1987], Rocco Capozzi [1989], Michael Davidson [1989], Mary Flowers Braswell [1995].

11 The term 'palimpsestuous' is used by Genette [1982] in Palimpsests. The adjective 'palimpsestic' is derived from the same concept. Dillon [2007: 45] summarizes the difference between them, explaining that "[w]here 'palimpsestic' refers to the process of layering that produces a palimpsest, 'palimpsestuous' describes the structure that one is presented with as a result of that process, and the subsequent reappearance of the underlying script."

12 I owe this interpretation to Professor Sofia Agranovich, who mentioned it during her brilliant lectures on history and theory of folklore at Samara State University (Samara, Russia). A similar interpretation is given by other scholars, e.g., Vardan Airapetyan [2001: 110].

13 Propp [1998] pays a great deal of attention to the rite of initiation explaining his morphological principle of analysis. For more specific details on the rite of initiation and other rites de passage, see Mircea Eliade [1965] and Bruno Bettelheim [Bettelheim 1976]. For examples of explaining the rite of initiation in familiar folk and fairy tales, see Bill Derry [1984].

14 On history of Tolstoy's creation of the ABC Book, see Eva Malenová [2010] and Irina Petrovitskaia [2013]. 
15 Russian classical literature is rich with literary tales, and a number of works available in Russian discuss various issues of this kind of tales [Abramiuk 1991; Anatolieva 1998; Braude 1979; Leonova 1982; Lipovetskii 1992; Lupanova 1981; Ovchinnikova 2001].

16 Here is Propp's terminological clarification: "The stability of construction of fairy tales permits a hypothetical definition of them which may be stated in the following way: a fairy tale is a story built upon the proper alternation of the above-cited functions in various forms, with some of them absent from each story and with others repeated. By such a definition the term "fairy" [volshebnyi] loses its sense, since it is a simple matter for one to imagine a wonderful, fantastic fairy tale constructed in a totally different way... On the other hand, non-fairy tales may also be constructed according to the scheme cited ... The term "fairy", therefore, ought to be replaced by another. Finding such a term is very difficult... If tales of this class are defined from a historical point of view, they then merit the antique, now discarded, name of mythical tales" [1968: 99-100].

17 Interpreting remakes has always been a controversial issue [Leitch 1990: 138-149; Horton 1998: 15-33, 327-334]. Opinions on remakes vary widely, from labeling some of them as 'parasitic' and potentially at risk of charges of plagiarism [Leitch, 138-139], to recognizing them as the only possible means of expression in the era when to "be in history is in a sense to be remade, to be copied. Jorge Luis Borges's "Pierre Menard, Author of the Quixote" is frequently invoked ... as a classic of meta-remaking. But it should be remembered that the heart of Pierre's remaking is to recopy Don Quixote word for word. The language, the chapter divisions, the punctuation, everything is the same. Only the historical moment has changed, and that, according to Borges, makes the text completely different" [Horton 1998: 329]. A particularly interesting aspect in the last example is that the narration in Borges' story represents Pierre Menard's Don Quixote as a palimpsest: "I have reflected that it is legitimate to see the "final" Quixote as a kind of palimpsest, in which the traces - faint but not undecipherable - of our friend's "previous" text must shine through" [1999: 95].

18 The formulations are taken from the English translation of Propp's Morphology [1968: 26-63]. For simplicity, I will use notation F1 (Function 1), etc., replacing Propp's Roman numbers with Arabic. Whenever possible, I will group some functions into units, for the sake of convenience, especially when functions are latent or absent.

19 Chernov [2006] offers a full analysis of all thirty-one functions.

20 The puppet cartoon Mashen 'ka i Medved' [Mashenka and the Bear] was produced in 1960 by director Roman Kachanov, the scenario is based on Georgii Landau's piece; the musical puppet animation Mashen'ka was released in 1992, director Sergei Olifirenko (both by the studio Soyuzmultfilm).

21 The Three Bears [1958], cartoon, director Roman Davydov, studio Soyuzmultfilm, and The Three Bears [1984], cartoon-opera, director Aida Ziablikova, studio Ekran.

22 For more detail, see http://mashabear.ru/projects/ 
23 See, for example, http://politikus.ru/video/30885-multfilm-masha-imedved-opasen-dlya-detey.html; http://www.bolshoyvopros.ru/questions/173735-vy-soglasny-chto-multikmasha-i-medved-nuzhno-zapretit.html;

http://biblepravda.com/page.php?id=885, and many other blogs, websites, and comments that condemn the cartoon as socially and psychologically harmful.

24 See the Animaccord Studio brochure at: http://www.animaccord.com/ assets/files/broshure_m.pdf.

25 The Song of Animal Tracks, lyrics by Vadim Zhuk, music by Vasily Bogatyryov:

Зверя по следам любого / Узнавать умею я! / И жирафа, и корову, / И жука, и воробья! / Чьи это следы петляют / Около лесных дорог? / Это по лесу гуляют / Нособраз и дикорог! / Нет, не то! Постойте, что-то... / Не другой ли зверь ходил? / А! Это след от крокомота! / Или это бегедил?.. / Нет, конечно!.. Да, конечно! / Будь уверен, не гадай. / По поляне ходят снежной / Попукан и пелигай! / Зверя по следам любого / Узнавать умею я! / И жукафа, и ворову, / И, конечно, коробья!

[I can tell any animal/ by its tracks:/ a giraffe and a cow, / a bug and a sparrow!/ Whose tracks are making loops here,/ Along the forest paths?/ Oh, it's a rhinopine and a porcunocerous/ wandering about./ Oh, no, this is not it! Hold on, it's... / Isn't that another animal walking? / Ah, it's a crocopotamus' track! / Or a hippodile's? / No, of course not! / Yes, of course yes! / Be sure, don't guess. / It's a parrican and pelirot trotting / On the snowy glade. / I can tell any animal/ by its tracks:/ a bugaffe and a sparcow,/ and of course a cowrow!/]

26 On children's etymology and other kinds of 'false', folk, and pseudoetymology, see Vvedenskaia and Kolesnikov [2003].

27 The term 'strategic reinvention' is suggested by Richard Pfefferman in his book Strategic Reinvention in Popular Culture: The Encore Impulse [2013] to distinguish a successful "encore" replication that retains the cherished value of the original from a mere formulaic imitation [2013: 2].

$28 \mathrm{Cf}$. http://www.animaccord.com/about/projects.html and http://mashabear.ru/projects/.

29 Playing with Lewis Carroll's original, Masha chooses to reinterpret Jabberwocky in Dina Orlovskaya's Russian translation [Carroll 1979: 189] and comes out with an even more nonsensical text:

Мракалось, тихно корабли прислухли на увал, / Лишь опоздалый попукан клухрым накарковал. / Вдруг загроохало скверча, молнует тучесвод. / Шагачит, злыками щелкча, огрущий Крокомот. / Зырками бешенски круча, но зверьно закручал / И астервлённо крюкача, морковку дёргать стал. 
[Tvas drillig, the ships quietyly gont halm, / And only a beelated parrican coarked cluckily. / Suddenly, it ruumbled sparklety; the cloudkin is litening. / It's the hugecreaming Crocopotamus is stompching, his evfangs clickening./ Rockling firiously his pupals, he beastckly scrumed,/ And, afrenzily hoinking, he started pulling carrots.]

30 More on paragrams, i.e., word plays, or puns, in postmodernism can be found at John Lechte: "In her work of the late 1960s...Kristeva uses the term 'paragram' (also used by Saussure)... because she is intent on emphasizing the idea that language is, in its essence, doubly constituted: it has a material base which insists poetically...in the textual message or in the text as a vehicle of communication. 'Paragram' rather than 'anagram', then, because the poet is not only creating poetic language, but is equally created by this language." [Lechte 2013: 78]

\section{BIBLIOGRAPHY}

"About Masha and the Bear", Animaccord. http://www.animaccord.com/assets/files/broshure_m.pdf. (consulted 20 March, 2015).

Akhmatova, Anna. 1995. Ахматова, Анна. Поэма без героя [Poem Without a Hero]. Санкт-Петербург: Библиополис.

Akhmatova, Anna. 2004. The Word That Causes Death's Defeat: Poems of Memory. Trans. by Nancy K. Anderson. New Heaven: Yale University Press.

Anikin, V.P. (ed.) 1978. Аникин, В.П. Русские народные сказки [Russian Folktales]. Москва: Детская литература.

Ayrapetyan, Vardan. 2001. Айрапетян, Вардан. Толкуя слово: Опыт герменевтики по-русски [Interpreting Word: An Attempt of a Hermeneutics in Russian]. Москва: Языки славянской культуры.

“Вы согласны, что мультик 'Маша и Медведь' нужно запретить?” [Do you agree that the cartoon 'Masha and the Bear' should be banned?]. Большой Bonpoc [Big Questions]. http://www.bolshoyvopros.ru/questions/173735vy-soglasny-chto-multik-masha-i-medved-nuzhno-zapretit.html (consulted 15 March, 2015).

Bettelheim, Bruno. 1976. The Uses of Enchantment. New York: Knopf: distributed by Random House.

Borges, Jorge Luis. 1999. Collected Fictions, transl. Andrew Hurley. New York: Penguin.

Braswell, Mary Flowers. 1995. "Chaucer's Palimpsest: Judas Iscariot and the Pardoner's Tale", Chaucer Review, vol. 29, no. 3. 303-310.

Capozzi, Rocco. 1989. "Palimpsests and Laughter: The Dialogical Pleasure of Unlimited Intertextuality in The Name of Rose", Italica, vol. 66, no. 4. 412428. 
Carroll, Lewis. 1979. Кэрролл, Льюис. Приключения Алисы в стране чудес. Алиса в Зазеркалье. [Alice's Adventures in Wonderland. Through the Looking-Glass]. Петрозаводск: Карелия.

Catullus. 1879. Select Poems of Catullus. Ed. by Francis Simpson. London: MacMillan \& Co.

Chai-Elsholz, Raeleen, Leo Carruthers and Tatjana Silec (eds.). 2011. Palimpsests and the Literary Imagination of Medieval England: Collected Essays (The New Middle Ages).

Chernov, Leonid. 2006. Чернов, Леонид. "Сказка Л. Толстого «Три медведя»" [L. Tolstoy's Fairytale Three Bears]. Seminarium Hortis Humanitatis. Cited by

http://seminariumhumanitatis.positiv.lv/15\%20almanax/15\%20sernov.htm (consulted 20 March 2015).

Cicero, Marcus Tullius. 2009. The Correspondence of M. Tullius Cicero. Vol. 4. Dublin: Hodges, Foster.

Colmer, Dorothy. 1970. "The Franklin's Tale": A Palimpsest Reading”, Essays in Criticism, vol. 20. 375-380.

Dal', Vladimir. 1862. Пословицы русскаго народа [The Proverbs of the Russian People]. Москва: Въ университетской типографіи.

Darby, David. 1987. "The Narrative Text as Palimpsest: Levels of Discourse" in Peter Handke's Die Hornissen", Seminar: A Journal of Germanic Studies, vol. 23, no.3. 251-264.

Davidson, Michael. 1989. "Palimtexts: Postmodern Poetry and the Material Text." in Postmodern Genres. Marjorie G. Perloff(ed). Norman: University of Oklahoma Press. 75-95.

De Quincey, Thomas. 2003. “The Palimpsest”, Confessions of an English Opium Eater. London: Penguin Classics. 144-152.

Derry, Bill. 1984. "We Want Our Rites! Folk and Fairy Tales as Initiation”, YaleNew Haven Teachers Institute, vol. IV. Cited by http://www.yale.edu/ynhti/curriculum/units/1984/4/84.04.07.x.html (consulted 15 March 2015).

Dillon, Sarah. 2007. The Palimpsest: Literature, Criticism, Theory. London and New York: Continuum.

Dovlatov, Sergey. 1993. Довлатов, Сергей. Собрание прозы в трех томах [Complete Works in Three Volumes]. Vol. 3. Санкт-Петербург: Лимбуспресс.

Eco, Umberto. 1994. The Name of the Rose. Trans. by William Weaver. Boston: Houghton Mifflin Harcourt.

Eliade, Mircea. 1965. Rites and Symbols of Initiation. New York: Harper \& Row.

Elms, Alan C. 1977. "The Three Bears': Four Interpretations". The Journal of American Folklore 90: 257-273.

Galisson, Robert. 1994. "Les palimpsestes verbaux: des révélateurs culturels remarquables, mais peu remarqués", Les Cahiers de l'ASDIFLE, 6, Actes des $13^{\mathrm{e}}$ et $14^{\mathrm{e}}$ Rencontres "Lexique et didactique du français langue étrangère." 
Galisson, Robert. 1995. "Des palimpsestes verbaux: des activateurs et des révélateurs culturels remarquables pour publics étrangers", ELA 97, Paris, Didier Erudition. 104-128.

Genette, Gérard. 1982. Palimpsestes: La littérature au second degré. Paris: Seuil. Graham, Mark. 2010. "Neogeography and the Palimpsests of Place", Tijdschrift voor economische en sociale geografie, v. 101 (4): 422-426.

Haines-Eitzen, Kim. 2011. The Gendered Palimpsest: Women, Writing, and Representation in Early Christianity. New York: Oxford University Press.

Horton, Andrew, and McDougal, Stuart Y. (eds.). 1998. Play it Again, Sam: Retakes on Remakes. Berkeley: University of California Press.

Jellinek, E. Morton. 1960. The Disease Concept of Alcoholism. New Haven: Hillhouse.

Khomich, E.P. 2006. Хомич, Э.П. “Фольклорный палимпсест литературной сказки (герменевтика смысла)" [A Folk Palimpsest of the Literary Tale (Hermeneutics of Sense)]. Anthropotext-1. Ed. by L.G. Kim. КемеровоТомск: Томский университет. 229-232.

Lechte, John. 2013. Julia Kristeva. New York: Routledge Library Editions.

Leitch, Thomas M. 1990. "Twice-Told Tales: The Rhetoric of the Remake", Literature Film Quarterly 18 (3): 138-149.

Lewes, Darby (ed.). 2008. Double Vision: Literary Palimpsests of the Eighteenth and Nineteenth Centuries. Lanham, MD: Lexington Books.

Lombroso-Ferrero, Gina. 1911. Criminal Man: According to the Classification of Cesare Lombroso. New York: The Knickerbocker Press.

Malenová, Eva. 2010. “Лев Николаевич Толстой - детский писатель. К восприятию «Азбуки» на чешском языке” [Lev Nikolayevich Tolstoy Children's Writer. On Perception of the $A B C$ Book in the Czech Language]. Opera Slavica, XX, 3: 39-43.

Martial. 1884. Extracts from Martial. Edinburgh: James Thin, Publisher to the University.

Masha and Bear [Маша и медведь]. 2006. Москва: ЗАО «Росмэн-Издат».

"Маша и Медведь - опасный детский мультфильм" [Masha and the BearDangerous Children's Cartoon]. Христианский взгляд [Christian View ]. http://biblepravda.com/page.php?id=885 (consulted 15 March, 2015).

McDonagh, Josephine. 1987. "Writings on the Mind: Thomas De Quincey and the Importance of the Palimpsest in Nineteenth-century Thought", Prose Studies, 10, 1. 207-224.

“Мультфильм «Маша и Медведь» опасен для детей” [Cartoon “Masha and the Bear" dangerous for children]. Politikus.ru http://politikus.ru/video/30885multfilm-masha-i-medved-opasen-dlya-detey.html (consulted 22 March, 2015).

Perloff, Marjorie G. (ed.). 1989. Postmodern Genres. Norman: University of Oklahoma Press.

Petrovitskaya, Irina. 2013. Петровицкая, Ирина. Лев Толстой-nублицист и общественный деятель [Lev Tolstoy-a Publicist and a Public Figure]. Москва: Икар. 
Pfefferman, Richard. 2013. Strategic Reinvention in Popular Culture: The Encore Impulse. New York: Palgrave Macmillan.

Plutarch. Maxime cum principibus philosopho esse disserendum. [Thesaurus Linguae Graecae: A Digital Library of Greek Litereature.]

Pouchkova, Svetlana. 2010. Vers un dictionnaire des mots à Charge Culturelle Partagée comme voie d'accès à une culture étrangère (FLE). (Le cas des apprenants immigrés adultes multiculturels). Thèse pour obtenir le grade de Docteur de 1'Université de Strasbourg. Strasbourg, Septembre 2010. Cited by

$\mathrm{http}: / /$ scd-theses.ustrasbg.fr/2052/01/POUCHKOVA_Sveltana_2010.pdf. (consulted 10 March 2015).

“Проекты" ['Projects']. Маша u Медведь [Masha and the Bear]. http://mashabear.ru/projects/ (consulted 15 March, 2015).

"Projects", Animaccord. http://www.animaccord.com/about/projects.html (consulted 15 March, 2015).

Propp, V. 1968. Morphology of the Folktale. University of Texas Press.

Propp, V. Үа. 1999. Проблемь комизма и смеха. Ритуальный смех в фольклоре (по поводу сказки о Несмеяне). (Собрание трудов В.Я. Проnna.) [Problems of the Comic and Laughter. Ritual Laughter in Folklore (Regarding the Folktale about Nesmeyana). (Works by V.Ya. Propp)]. Москва: Лабиринт.

Propp, V.Yа. 1998. Пропп, В.Я. Морфология “волшебной” сказки. Исторические корни волшебной сказки. (Собрание трудов В. Я. Пропna) [Morphology of the 'Fairy' Tale. Historical Roots of the Fairy Tale]. Москва: Лабиринт.

Russell, Charles William. 1867. "Palimpsest literature, and its editor, Cardinal Angelo Mai", The Afternoon Lectures on Literature and Art. London: Bell and Daldy. 96-132.

Tatar, Maria. 2002. The Annotated Classic Fairy Tales. New York: W.W. Norton \& Company.

Thompson, Sir Edward Maunde. 2013. An Introduction to Greek and Latin Palaeography. Cambridge: Cambridge University Press.

Tolstoy, L. N. 1978. Толстой, Л.Н. Собрание сочинений в двадияати двух mомах [Complete Works in Twenty-two Volumes]. Москва: Художественная литература.

Uricchio, William. 2012. "A Palimpsest of Place and Past", Performance Research: A Journal of the Performing Arts, 17 (3): 45-49.

Vvedenskaya, L.A., Kolesnikov, N.P. 2003. Введенская, Л.А., Колесников, Н.П. "Приемы осмысления внутренней формы слова (виды ненаучной этимологии)" [Ways of Interpretation of the Inner Form of the Word], Respectus Philologicus, 2003 (3), http://filologija.vukhf.lt/3-8/vved.htm.

Zalizniak, Andrey. 2002. Зализняк, Андрей. “Тетралогия «От язычества к Христу» из Новгородского кодекса ХІ века" [Tetralogy "From Paganism to Christ" from the Novgorod Codex of the $11^{\text {th }}$ Century], Русский язык 8 научном освещении, 2 (4): 35-56. 